\title{
Pemanfaatan Abu Tongkol Jagung sebagai Alternatif Katalis Basa pada Pembuatan Biodiesel dari Minyak Jelantah
}

Risna Erni Yati Adu

Program Studi Kimia,, Universitas Timor, Kefamenanu, TTU - NTT, Indonesia, email: adoe.risna@yahoo.com

\section{Article Info}

Article history:

Received 18 Mei 2020

Received in revised form $22 \mathrm{Mei} 2020$

Accepted 25 Mei 2020

\section{DOI:}

\section{Keywords:}

Abu tongkol jagung,

biodiesel,

minyak jelantah,

katalis basa https://doi.org/10.32938/slk.v3i1.1017

Abstrak

Pemanfaatan abu tongkol jagung sebagai sumber alternatif katalis basa pada pembuatan biodiesel telah dikaji. Hal in dilakukan untuk mengetahui potensi abu tongkol jagung pada penggunaannya sebagai katalis basa dalam transesterifikasi minyak jelantah. Pengukuran sifat alkali abu tongkol jagung dilakukan dengan AAS untuk menentukan kadar kalium dan uji alkalinitas untuk menentukan kandungan karbonat. Larutan alkali diperolehh melalui pengadukan abu tongkol jagung dalam metanol selama 4 jam dan selanjutnya digunakan untuk reaksi transesterifikasi minyak jelantah dengan variasi massa abu untuk 5, 10, 15, dan $20 \mathrm{gr}$ (rasio molar metanol/minyak 6:1, waktu reaksi 2 jam, temperatur $60^{\circ} \mathrm{C}$ dan kecepatan pengadukan dijaga konstan); dan variasi rasio molar metanol/minyak untuk 3:1, 6:1, 9:1 dan 12:1(massa abu optimum). Komponen metil ester hasil transesterifikasi ditentukan dengan GC-MS, sedangkan beberapa sifat fisika dan kimia biodiesel diukur menggunakan metode standar ASTM

Hasil penelitian menunjukkan bahwa kadar kalium yang terkandung dalam abu tongkol jagung berada dalam bentuk kalium karbonat dengan konsentrasi kalium sebesar $38,76 \%$ (b/b). Konversi biodiesel mencapai kondisi optimum pada pengounaan massa abu 10 gr dan rasio molar metanol/minyak 6:1. Berdasarkan data GC-MS dapat diketahui bahwa hasil sintesis biodiesel merupakan metil ester yang didominasi oleh metil linoleat dan metil palmitat. Kualitas produk biodiesel (viskositas dan densitas) memenuhi persyaratan spesifikasi biodiesel menurut SNI 7182-2015. Dengan demikian abu tongkol jagung dapat digunakan sebagai alternatif sumber katalis basa pada transesterifikasi minyak jelantah. Pemanfaatan abu tongkol jagung pada transesterifikasi dapat menambah nilai ekonomis minyak jelantah maupun tongkol jagung.

\section{Pendahuluan}

Kelangkaan Bahan Bakar Minyak (BBM) masih menjadi salah satu masalah krusial bagi bangsa Indonesia. Pasokan BBM dalam negeri terbatas akibat laju produksi yang cenderung lebih rendah dibandingkan dengan tingkat konsumsi masyarakat. Selain itu, cadangan bahan bakar fosil di Indonesia yang semakin berkurang karena bersifat tidak dapat diperbaharui. Pemerintah telah berupaya untuk mengatasi persoalan ini dengan mengeluarkan kebijakan tentang penyediaan dan pemanfaatan bahan bakar nabati sebagai alternatif bahan bakar fosil (Instruksi Presiden No. 1 Tahun 2006). Hal ini cukup beralasan karena Indonesia merupakan negara penghasil minyak nabati terbesar di dunia yang cukup potensial untuk dikembangkan menjadi biodiesel yang ramah lingkungan dan dapat diperbaharui.

Biodiesel dapat disintesis melalui reaksi transesterifikasi minyak nabati dengan alkohol menggunakan katalis basa. Kajian tentang biodiesel telah banyak dipublikasikan, akan tetapi perkembangan penggunaannya secara komersial tidak secepat perkembangan teknologinya sebagai akibat dari biaya produks biodiesel yang lebih tinggi dibandingkan dengan penggunaan bahan bakar petrodiesel. Sehingga untuk menekan biaya produksi biodiesel telah dilakukan berbagai cara, salah satunya adalah pemanfaatan katalis basa alternatif yang lebih ekonomis. Telah dilakukan pemanfaatan abu Tandan Kosong Sawit (TKS) sebagai sumber katalis basa konvensional $\left(\mathrm{K}_{2} \mathrm{CO}_{3}\right)$ pada pembuatan biodiese dari minyak biji sawit melalui reaksi transesterifikasi dan diperoleh konvers biodiesel optimum sebesar $69,67 \%$ pada rasio massa abu terhadap minyak $6 \%$ (Yoeswono $d k k ., 2007$ ). Abu TKS juga digunakan sebagai katalis pada reaksi transesterifikasi minyak sawit dan diperoleh persen konversi tertinggi sebesar 97,8 pada penggunaan massa abu $10 \%$ terhadap berat minyak (Imaduddin $d k k$. 2008). Abu TKS berpotensi untuk digunakan sebagai alternatif katalis basa konvensional karena abu hasil pembakaran TKS mempunyai kadar kalium yang tinggi yakni sekitar 20-40 \% yang dapat bersifat alkali ketika dilarutkan dalam air (Sibarani $d k k ., 2007)$

Salah satu sumber alternatif katalis konvensional lain yang lebih efisien adalah abu tongkol jagung (ATJ). Tongkol jagung merupakan salah satu agrowaste yang mudah diperoleh dan tersedia dalam jumlah melimpah. Abu yang diperoleh dari pembakaran tongkol jagung mempunyai kadar kalium yang bervariasi dan cukup tinggi yakni 7,26 mg/gr sebagai $\mathrm{K}_{2} \mathrm{CO}_{3}$ (Wannapeera $d k k$. 2008), 4,23\% dalam bentuk $\mathrm{K}_{2} \mathrm{O}$ (Owolabi $d k k$., 2015). Meskipun demikian berdasarkan penelusuran literatur belum ada kajian tentang potensi tongkol jagung sebagai sumber alternatif katalis basa pada pembuatan biodiesel. Oleh karena itu pada penelitian ini penulis memanfaatkan abu tongkol jagung sebagai sumber alternatif katalis basa konvensional yang lebih ekonomis dan ramah lingkungan. Abu tongkol jagung dilarutkan menjadi larutan yang bersifat alkalis yang dapat mengkatalisis reaksi transesterifikasi. Minyak yang digunakan pada transesterifikasi adalah minyak jelantah yang merupakan minyak sisa hasi penggorengan yang telah mengalami proses oksidasi maupun hidrolisis. Kandungan asam lemak bebas minyak jelantah diesterifikasi dengan metanol menghasilkan biodiesel (Chai $d k k$., 2014). Sedangkan kandungan trigliserida ditransesterifikasi dengan metanol, yang juga menghasilkan biodiesel dan gliserol. Konversi minyak jelantah menjadi biodiesel dapat menambah nilai ekonomis minyak jelantah.

\section{Metode}

\subsection{Preparasi abu tongkol jagung}

Tongkol jagung dibersihkan, dihaluskan dan dipanaskan menggunakan oven pada temperatur $110{ }^{\circ} \mathrm{C}$ selama 2 jam untuk menghilangkan air kemudian disaring dengan ayakan 100 mesh. Selanjutnya abu diabukan kembali (reashing) sampai temperatur $700{ }^{\circ} \mathrm{C}$ untuk menghilangkan sisa-sisa karbon. Analisis terhadap abu tongkol jagung meliputi penentuan kadar air, kadar abu, uji kelarutan dalam air dan alkohol, penentuan kadar kalium serta kandungan karbonat dalam abu. Penentuan kadar kalium dalam abu tongkol jagung dilakukan dengan spektrometer serapan atom (AAS, Varian FS 220) serta untuk mengetahui keberadaan ion karbonat dilakukan uji alkalinitas.

\subsection{Transesterifikasi minyak jelantah}

Sejumlah tertentu abu ATJ diaduk dalam $75 \mathrm{~mL}$ metanol selama 4 jam pada temperatur $60^{\circ} \mathrm{C}$. Setelah disaring, ekstrak yang diperoleh dicukupkan volumenya sehingga diperoleh rasio molar metanol/minyak tertentu yang akan digunakan untuk melakukan reaksi transesterifikasi terhadap 50 gr minyak jelantah yang telah dimurnikan. Reaksi transesterifikasi dilakukan selama 2 jam sambil diaduk. Setelah reaksi berjalan 2 jam, campuran yang terbentuk dituang dalam corong pisah, dibiarkan terjadi pemisahan selama 2 jam pada temperatur kamar. Lapisan metil ester yang terbentuk dipisahkan dari lapisan gliserol, selanjutnya didistilasi sampai temperatur $74{ }^{\circ} \mathrm{C}$ untuk menghilangkan sisa metanol. Penghilangan sisa katalis dan gliserol dalam metil ester dilakukan dengan pencucian menggunakan air secara berulang hingga diperoleh lapisan air jernih. Kemudian metil ester dikeringkan dengan penambahan $\mathrm{Na}_{2} \mathrm{SO}_{4}$ anhidrat p.a. (Merck). Prosedur proses transesterifikasi tersebut dilakukan dengan variasi massa abu untuk 5, 10, 15, dan 20 gr (rasio molar metanol/minyak 6:1, waktu reaksi 2 jam, temperatur $60^{\circ} \mathrm{C}$ dan kecepatan pengadukan dijaga konstan); variasi rasio molar metanol/minyak untuk 3:1, 6:1, 9:1 dan 12:1 (massa abu optimum, waktu reaksi $2 \mathrm{jam}$, temperatur $60^{\circ} \mathrm{C}$, dan kecepatan pengadukan dijaga konstan) dan variasi suhu $30,40,50,60$ dan $70{ }^{\circ} \mathrm{C}$ (massa abu optimum, waktu reaksi 2 jam, rasio metanol/minyak 6:1 dan kecepatan pengadukan dijaga konstan).

\subsection{Analisis hasil transesterifikasi}

Komposisi metil ester minyak jelantah dianalisis menggunakan kromatografi gas-spektrometer massa (GC-MS). Kualitas biodiesel diuji dengan metode uji ASTM D 1298, ASTM D 445, dan ASTM D 6584 yang diadopsi dalam SNI 7182:2015.

\section{Hasil dan Pembahasan}

\subsection{Karakteristik dan Komposisi Abu Tongkol Jagung}

Penentuan karakteristik dan komposisi abu tongkol jagung meliput kadar air, kadar abu, serta sifat kelarutan abu dalam air maupun alkohol, kandungan kalium, dan alkalinitas. Hasil penelitian menunjukkan kadar air dan kadar abu dalam tongkol jagung secara berturut-turut sebesar $28,90 \%$ dan $6,9 \%$ (6,9 gr abu per 100 gr tongkol jagung). Perolehan kadar abu yang tinggi disebabkan oleh kandungan mineral dalam tongkol jagung yang tinggi serta metode pengabuan yang menggunakan suhu $700^{\circ} \mathrm{C}$, dimana masih kurang optimal untuk mengoksidasi seluruh komponen organik yang terkandung di dalam tongkol jagung. Sifat kelarutan abu tongkol jagung dalam air sebesar 30,84 $\%$ atau sekitar 4,5 gr per 10 gr air. Sedangkan di dalam alkohol sebesar $12,01 \%$ atau sekitar 1,5 gr per $10 \mathrm{gr}$ alkohol. Abu tongkol jagung memiliki sifat lebih mudah larut dalam air dibandingkan dengan alkohol karena sifat alkohol yang merupakan pelarut semipolar, sehingga kurang mampu melarutkan mineralmineral anorganik yang cenderung bersifat polar. Berdasarkan hasil analisis SSA, kadar kalium yang terdapat pada abu tongkol jagung mencapai 38,76\%. Level konten kalium dalam tongkol jagung dipengaruhi oleh jenis mineral pembentuk tanah dan kondisi cuaca setempat. Persediaan kalium di dalam tanah 
dapat berkurang dengan adanya dua hal, yaitu pencucian kalium oleh air dan erosi tanah.

Tabel 3.1. Konsentrasi Anion dalam Abu Tongkol Jagung

\begin{tabular}{cc}
\hline Alkalinitas & Konsentrasi (g/kg) \\
\hline $\mathrm{HCO}_{3}{ }^{-}$(bikarbonat) & 150 \\
$\mathrm{CO}_{3}{ }^{2-}$ (karbonat) & 560,28 \\
\hline
\end{tabular}

Perhitungan secara asidi-alkalimetri pada Tabel 3.1. menunjukkan bahwa kadar ion bikarbonat jauh lebih rendah daripada kadar ion karbonat. Dengan demikian dapat disimpulkan bahwa kalium yang terdapat dalam abu tongkol jagung sebagian besar berbentuk kalium karbonat $\left(\mathrm{K}_{2} \mathrm{CO}_{3}\right)$. Hal ini terjadi karena semua logam kalium yang dihasilkan dari pengabuan tongkol jagung berkarbonasi dengan karbondioksida membentuk garam karbonat yang stabil pada suhu yang tinggi.

\subsection{Pengaruh massa abu Tongkol jagung terhadap Produk Biodiesel}

Reaksi transesterifikasi minyak jelantah dilakukan menggunakan rasio metanol/minyak $6: 1$ pada temperatur $60^{\circ} \mathrm{C}$, dengan katalis basa $\mathrm{K}_{2} \mathrm{CO}_{3}$ dari abu tongkol jagung di dalam media metanol selama dua jam. Transesterifikasi dilakukan dengan melakukan variasi massa abu tongkol jagung yaitu: 5, 10,15 dan 20 gram. Pengaruh massa abu terhadap konversi biodiesel ditampilkan pada Tabel 3.2 berikut:

Tabel 3.2. Pengaruh massa abu terhadap persen konversi biodiesel

\begin{tabular}{cccl}
\hline No & $\begin{array}{c}\text { Kode (massa abu/rasio metanol } \\
\text { :minyak /suhu/waktu) }\end{array}$ & $\begin{array}{c}\text { Massa } \\
\text { abu (gr) }\end{array}$ & $\begin{array}{c}\text { Konve } \\
\text { rsi (\%) }\end{array}$ \\
\hline 1 & $5 / 6: 1 / 60 / 2$ & 5 & 99,03 \\
2 & $10 / 6: 1 / 60 / 2$ & 10 & 100 \\
3 & $15 / 6: 1 / 60 / 2$ & 15 & 97,53 \\
4 & $20 / 6: 1 / 60 / 2$ & 20 & 96,52 \\
\hline
\end{tabular}

Peningkatan jumlah abu tongkol jagung dalam reaksi transesterifikasi tidak meningkatkan konversi biodiesel yang diperoleh. Pada penggunaan massa abu tongkol jagung 5, 10, 15, dan 20 gr diperoleh konversi biodiesel berurutturut: 99,$03 ; 100 ; 97,53$; dan 96,52\%. Data ini menunjukkan bahwa peningkatan jumlah massa abu cenderung meningkatkan konversi biodiesel, akan tetapi pada keadaan tertentu dicapai kondisi optimum reaksi. Penggunaan massa abu 5 gr diperoleh konversi biodiesel sebesar 99,03\%. Hal ini terjadi karena jumlah situs aktif dari abu yang digunakan belum maksimal untuk dapat bereaksi dengan metanol membentuk metoksida. Selanjutnya pada penggunaan massa abu 10 gram, diperoleh konversi $100 \%$ yang menunjukkan kondisi optimum reaksi dalam variasi massa abu tongkol jagung. Konversi biodiesel cenderung menurun pada penggunaan abu 15 dan 20 gr yaitu sebesar 97,53 dan 96,52\%. Penurunan persen konversi terjadi akibat berkurangnya nukleofil metoksida yang dihasilkan dari reaksi $\mathrm{K}_{2} \mathrm{CO}_{3}$ dan metanol karena adanya reaksi kompetitif antara elemenelemen lain abu yang berlebih di dalam sistem, serta larutan methanol-ATJ yang telah menjadi jenuh. Hal ini menyebabkan interaksi nukleofil dengan trigliserida menjadi lemah.

Mekanisme reaksi pada transesterifikasi terkatalisis basa diawali dengan reaksi katalis $\mathrm{K}_{2} \mathrm{CO}_{3}$ dengan metanol menghasilkan kalium metoksida yang merupakan suatu nukleofil kuat yang selanjutnya menyerang atom karbon karbonil trigliserida menghasilkan zat antara (intermediate), kemudian zat antara yang terbentuk mengalami eliminasi (pemutusan gugus asil) yang diikuti terbentuknya metil ester dan ion gliserida. Pada tahap akhir reaksi ion gliserida bereaksi dengan asam karbonat menghasilkan gliserol dan kalium karbonat kembali (Asri $d k k ., 2015$ ).

\subsection{Pengaruh Rasio Molar metanol/Minyak terhadap produk Biodiesel}

Pengaruh rasio molar metanol/minyak terhadap persen konversi biodiesel dikaji pada penelitian ini dengan melakukan transesterifikasi pada temperatur $60^{\circ} \mathrm{C}$, dengan katalis basa $\mathrm{K}_{2} \mathrm{CO}_{3}$ dari abu tongkol jagung di dalam media metanol selama dua jam dengan variasi rasio molar metanol/minyak $3: 1$, 6:1, 9:1, dan 12:1 (Tabel 3.3).

\begin{tabular}{|c|c|c|c|}
\hline No & $\begin{array}{l}\text { Kode (massa abu/rasio } \\
\text { metanol:minyak } \\
\text { /suhu/waktu) }\end{array}$ & Rasio & Konversi (\%) \\
\hline 1 & $10 / 3: 1 / 60 / 2$ & $3: 1$ & 87 \\
\hline 2 & $10 / 6: 1 / 60 / 2$ & $6: 1$ & 100 \\
\hline 3 & $10 / 9: 1 / 60 / 2$ & $9: 1$ & 92,5 \\
\hline 4 & $10 / 12: 1 / 60 / 2$ & $12: 1$ & 90,5 \\
\hline
\end{tabular}

Berdasarkan data pada Tabel 3.3, persentase konversi biodiesel meningkat seiring dengan semakin besar rasio molar metanol/minyak. Penggunaan metanol berlebih dapat menggeser reaksi kesetimbangan ke arah pembentukan produk untuk menghasilkan konversi yang maksimum. Penggunaan rasio molar yang tinggi dapat menyebabkan pemisahan gliserol menjadi sulit karena peningkatan kelarutan gliserol (Phan \& Phan, 2008). Semakin tinggi alkohol yang digunakan dapat menurunkan viskositas biodiesel sehingga akan menurunkan titik nyala biodiesel, akibat sifat alkohol yang mudah terbakar. Peningkatan kelarutan gliserol dalam metil ester akan mendorong reaksi berbalik ke reaktan dengan membentuk monogliserida, serta terjadi pembentukan buih dalam fase ester menyebabkan rendemen metil ester menjadi berkurang (Encinar $d k k$., 2005). Pada penelitian ini, transesterifikasi dengan katalis basa pada rasio molar alkohol/minyak yang lebih dari 6:1 tidak meningkatkan hasil konversi alkil ester secara signifikan.

\subsection{Pengaruh Suhu terhadap Reaksi Transesterifikasi}

Suhu memiliki pengaruh signifikan terhadap reaksi transesterifikasi. Reaksi transesterifikasi dapat dilakukan pada berbagai suhu tergantung pada sifat-sifat minyak yang digunakan. Pengaruh suhu terhadap reaksi transesterifikasi minyak jelantah menggunakan abu tongkol jagung dipelajari dengan melakukan variasi suhu pada $30,40,5060,70$ dan $80{ }^{\circ} \mathrm{C}$, hasilnya ditunjukkan pada Gambar 3.4. Kenaikan suhu dari $30-60^{\circ} \mathrm{C}$ meningkatkan laju reaksi sehingga rendemen produk juga cenderung meningkat hingga 32,04\% Konversi biodiesel minyak jelantah mencapai kondisi optimum pada suhu $60^{\circ} \mathrm{C}$ sebesar $99,75 \%$. Kenaikan suhu yang lebih tinggi dari dari $60^{\circ} \mathrm{C}$ menurunkan persen konversi biodiesel. Penggunaan suhu yang melampaui titik didih alkohol menurunkan laju reaksi konversi metil ester karena terjadi volatilisasi alkohol. Di sisi lain kenaikan suhu yang sangat tinggi mempercepat laju reaksi saponifikasi yang dapat menghambat pembentukan metil ester(Phan \& Phan, 2008).

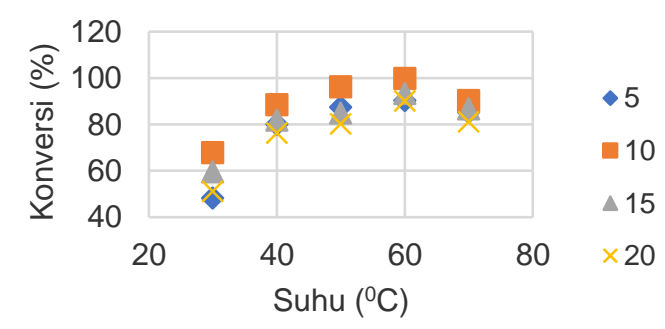

Gambar 3.4. Pengaruh suhu terhadap Transesterifikasi

\subsection{Analisis Hasil Transesterifikasi}

Hasil analisis sampel biodiesel untuk pada massa abu tongkol jagung optimum dengan kromatografi gas dapat dilihat pada gambar berikut:

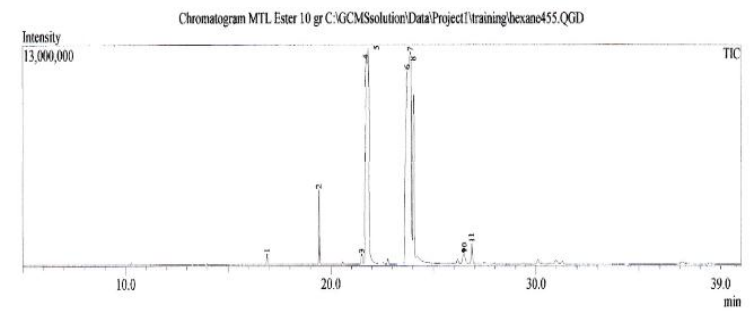

Gambar 3.5. Kromatogram Hasil Transesterifikasi untuk massa abu 10g

Secara keseluruhan senyawa metil ester penyusun biodiesel dari minyak jelantah dapat dilihat pada Tabel 3.4 berikut:

Tabel 3.4. Komponen Metil Ester

\begin{tabular}{llll} 
Nama Senyawa & $\begin{array}{l}\text { Waktu } \\
\text { Retensi }\end{array}$ & Puncak & $\begin{array}{l}\text { Luas } \\
\text { Puncak } \\
(\%)\end{array}$ \\
\hline Metil linoleat & 23,758 & 6 & 35,02 \\
Metil palmitat & 21,733 dan & 4 dan 5 & 20,53 dan \\
Metil oleat & 21,844 & & 13,03 \\
Metil stearat & 23,906 & 7 & 14,62 \\
Metil miristat & 24,048 & 8 & 10,02 \\
Metil arakidat & 19,437 & 2 & 2,99 \\
Metil laurat & 26,875 & 11 & 1,18 \\
Metil trans-9,10- & 16,896 & 1 & 0,39 \\
epoksistearat & 26,502 & 10 & 0,44 \\
Metil palmitoleat & 21,504 & 3 & 0,59 \\
Metil eikosenoat & 26,502 & 9 & 1,20 \\
\hline
\end{tabular}

Data MS menunjukkan bahwa hasil sintesis penelitian ini merupakan senyawa biodiesel yakni metil ester. Konversi metil ester hasil didominasi oleh asam lemak tak jenuh ganda yaitu asam linoleat (C18-2) sebesar 35,02\%; asam lemak tak jenuh tunggal diantaranya asam palmitat (C16-1) dan asam oleat (C181) berturut-turut sebesar 13,03 dan $14,62 \%$; dan asam lemak jenuh rantai panjang seperti asam stearate (C18-0) sebesar $10,02 \%$. Metil ester yang muncul pada spektra sesuai dengan kandungan asam lemak yang terdapat pada minyak nabati yang digunakan untuk sintesis biodiesel seperti asam laurat, asam palmitoleat, asam palmitat, asam miristat, asam linoleat, asam oleat, asam stearat, dan asam 11-eikosenoat. Sedangkan metil trans-9,10-epoxystearat tidak sesuai dengan kandungan asam-asam lemak pada minyak nabati. Senyawa yang tidak sesuai 
diduga berasal dari hasil transesterifikasi asam lemak yang berasal dari bahan makanan yang digoreng. Metil trans-9,10-epoxystearat merupakan hasil reaksi oksidasi ikatan rangkap pada asam lemak tak jenuh oleh oksigen aktif membentuk senyawa epoksida akibat prosen penggorengan menggunakan minyak secara berulang. Proses penggorengan yang berulang-ulang pada suhu yang tinggi menyebabkan terjadinya perubahan geometris pada asam-asam lemak tak jenuh akibat proses oksidasi (Sartika, 2010).

\subsection{Uji Kualitas Biodiesel}

Sifat-sifat biodiesel sebagai bahan bakar diukur berdasarkan parameterparameter seperti viskositas, berat jenis, bilangan iod, gliserol total dan gliserol bebas. Hasil yang diperoleh ditampilkan pada Tabel 3.5. Densitas merupakan perbandingan berat dari suatu volume sampel pada suhu $25^{\circ} \mathrm{C}$ dengan berat air pada suhu dan volume yang sama, yang berkaitan dengan nilai kalor dan daya yang dihasilkan oleh mesin diesel per satuan volume bahan bakar. Densitas juga sering dihubungkan dengan fraksi berat komponen-komponen yang terkandung di dalamnya. Semakin besar fraksi berat yang terkandung dalam minyak, maka semakin besar pula nilai densitasnya (Feriyanto $d k k$., 2013). Dari tabel 3.5 terlihat bahwa densitas biodiesel yang diperoleh pada suhu $30^{\circ} \mathrm{C}$ memenuhi range standar kualitas biodiesel menurut SNI 7182:2015 yaitu 0,85-0,90 g/mL.

Viskositas atau kekentalan merupakan tahanan yang dimiliki fluida yang dialirkan dalam pipa kapiler terhadap gaya gravitasi, dinyatakan dalam waktu yang diperlukan untuk mengalir pada jarak tertentu. Viskositas biodiesel pada umumnya ditentukan oleh jumlah dan jenis asam lemak yang terkandung dalam biodiesel. Biodiesel harus mempunyai kekentalan yang relatif rendah agar dapat mudah mengalir dan teratomisasi. Jika kekentalan semakin tinggi, maka tahanan untuk mengalir akan semakin tinggi sehingga membuat bahan bakar sulit untuk mengalir dalam pipa kapiler yang berdiameter kecil. Sedangkan biodiesel dengan kekentalan lebih rendah memproduksi percikan yang terlalu halus dan tidak dapat masuk lebih jauh ke dalam silinder pembakaran, sehingga menyebabkan pemborosan bahan bakar (Graboski \& McCormick, 1998). Berdasarkan Tabel 3.5 tersebut terlihat bahwa nilai viskositas kinematik minyak pada suhu $40^{\circ} \mathrm{C}$ berada pada range $2,3-6,0 \mathrm{~mm}^{2} / \mathrm{s}(\mathrm{cSt})$, sehingga memenuhi persyaratan kualitas biodiesel menurut SNI 7182:2015. Kadar gliserol bebas dan gliserol total pada penelitian ini melebihi nilai maksimum standar SNI untuk semua variasi berat katalis. Adanya senyawa gliserida dalam bentuk gliserol bebas dan gliserol total dalam biodiesel disebabkan oleh konversi minyak nabati yang kurang sempurna selama proses transesterifikasi atau adanya reaksi balik antara gliserin dan metil ester (Setiawati \& Edwar, 1999).

Tabel 3.5. Sifat Fisika-Kimia Biodiesel

\begin{tabular}{|c|c|c|c|c|c|c|}
\hline \multirow{2}{*}{ Sifat } & \multirow{2}{*}{$\begin{array}{c}\text { Metode } \\
\text { ASTM }\end{array}$} & \multirow{2}{*}{$\begin{array}{l}\text { Syarat } \\
\text { SNI } \\
7182: 201 \\
5\end{array}$} & \multicolumn{4}{|c|}{ Massa abu(gram) } \\
\hline & & & 5 & 10 & 15 & 20 \\
\hline $\begin{array}{l}\text { Viskositas } \\
\text { (cSt) }\end{array}$ & D 445 & $2,3-6,0$ & 3,83 & 3,96 & 3,96 & 4,09 \\
\hline $\begin{array}{l}\text { Densitas } \\
\left(\mathrm{kg} / \mathrm{m}^{3}\right)\end{array}$ & D 1298 & $850-890$ & 880 & 880 & 880 & 880 \\
\hline $\begin{array}{l}\text { Gliserol } \\
\text { bebas (\% } \\
\text { b/b), maks }\end{array}$ & D 6584 & 0,02 & 0,037 & 0,034 & 0,40 & 0,051 \\
\hline $\begin{array}{l}\text { Gliserol } \\
\text { total (\% } \\
\text { b/b), maks }\end{array}$ & D 6584 & 0,24 & 0,43 & 0.35 & 0,31 & 0,27 \\
\hline
\end{tabular}

\section{Simpulan}

Abu tongkol jagung mempunyai kandungan kalium yang cukup tinggi yakni $38,76 \%$ dalam bentuk $\mathrm{K}_{2} \mathrm{CO}_{3}$ yang dapat digunakan pada transesterifikasi minyak jelantah. Analisis komponen metil ester dengan GC-MS menunjukkan bahwa metil ester yang dihasilkan merupakan konversi dari asam-asam lemak penyusun utama minyak nabati. Kualitas biodiesel hasil transesterifikasi minyak jelantah memiliki sifat sebagai berikut: berat jenis $0,880 \mathrm{gr} / \mathrm{mL}$, viskositas sebesar 3,96 cSt, gliserol bebas dan gliserol total sebesar 0,034 dan 0,35\%. Kualitas biodiesel memenuhi standar kualitas biodiesel menurut SNI 7182:2015. Oleh karena itu abu tongkol jagung dapat digunakan sebagai sumber alternatif katalis basa untuk transesterifikasi minyak jelantah.

\section{Pustaka}

Asri, N., Sari, D. \& Poedjojono, B. 2015. Pre-treatment of waste frying oils for biodiesel production. Modern Applied Science, 9(7): 99-106.

Chai, M., Tu, Q., Lu, M. \& Yang, Y.J. 2014. Esterification pretreatment of free fatty acid in biodiesel production, from laboratory to industry. Fuel processing technology, 125: 106-113.

Encinar, J.M., González, J.F. \& Rodríguez-Reinares, A. 2005. Biodiesel from used frying oil. Variables affecting the yields and characteristics of the biodiesel. Industrial \& Engineering Chemistry Research, 44(15): $5491-5499$.
Feriyanto, Y.E., Sipahutar, P.J., Mahfud, M. \& Prihatini, P. 2013. Pengambilan Minyak Atsiri dari Daun dan Batang Serai Wangi (Cymbopogon winterianus) Menggunakan Metode Distilasi Uap dan Air dengan Pemanasan Microwave. Jurnal Teknik ITS, 2(1): F93-F97.

Graboski, M.S. \& McCormick, R.L. 1998. Combustion of fat and vegetable oil derived fuels in diesel engines. Progress in energy and combustion science, 24(2): 125-164.

Imaduddin, M., Yoeswono, Y. \& Tahir, I. 2008. Ekstraksi kalium dari abu tandan kosong sawit sebagai katalis pada reaksi transesterifikasi minyak sawit. Bulletin of Chemical Reaction Engineering \& Catalysis, 3(13): 14-20.

Owolabi, T., Oladipo, I. \& Popoola, O. 2015. Effect of Corncob Ash as Partial Substitute For Cement In Concrete [J]. New York Science Journal, 8(11): $1-4$

Phan, A.N. \& Phan, T.M. 2008. Biodiesel production from waste cooking oils. Fuel, 87(17-18): 3490-3496.

Sartika, R.A.D. 2010. Pengaruh suhu dan lama proses menggoreng (deep frying) terhadap pembentukan asam lemak trans. Makara Journal of Science.

Setiawati, E. \& Edwar, F. 1999. Teknologi pengolahan biodiesel dari minyak goreng bekas dengan teknik mikrofiltrasi dan transesterifikasi sebagai alternatif bahan bakar mesin diesel. Jurnal Riset Industri Online, 6(2).

Sibarani, J., Khairi, S., Yoeswono, Y., Wijaya, K. \& Tahir, I. 2007. Effect of palm empty bunch ash on transesterification of palm oil into biodiesel. Indonesian Journal of Chemistry, 7(3): 314-319.

Wannapeera, J., Worasuwannarak, N. \& Pipatmanomai, S. 2008. Product yields and characteristics of rice husk, rice straw and corncob during fast pyrolysis in a drop-tube/fixed-bed reactor. Songklanakarin Journal of Science \& Technology, 30(3).

Yoeswono, Y., Triyono, T. \& Tahir, I. 2007. Pemanfaatan Limbah Abu Tandan Kosong Sawit Sebagai Katalis Basa Pada Pembuatan Biodiesel Dari Minyak Sawit (Ash Waste from Empty Palm Fruit Bunches as Base Catalyst for Biodiesel Synthesis from Palm Oil). Jurnal Manusia dan Lingkungan, 14(2): 55-62. 